maintained during the war by rationing home grown timber and drastically overcutting woods, particularly to make the pit props essential to the production of the coal on which the war effort depended. To ensure that such a situation would not arise again, the Forestry Act of 1919 set up the Forestry Commission, and by 1939, 600,000 acres of woods had been planted. Since the Second World War large scale expansion has produced the $1,646,180$ acres now under plantation.

The story of the first fifty years is told in a Forestry Commission booklet, Timber! Your Growing Investment (HMSO, 6s 6d), which predicts that by 1978 Britain will have $3,700,000$ acres of well managed woods, including 200,000 on private estates. Apart from two Royal domains, Eggesford Forest and the Forest of Dean, which the commission took over early in its life, the management of existing woods has been left to private owners, often with financial and technical help from the commission. Under the dedication scheme, which began in 1947, private owners who receive financial aid covenant to use their woods for timber production and to manage them to an approved plan. Other owners with very small or scattered woods

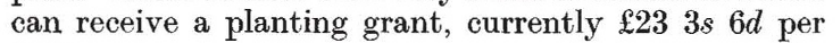
acre.

During its fifty years the commission has developed many improved methods of growing and harvesting timber, built its own roads and bridges, set up research centres, and learnt to deal with its greatest danger, fire. The commission has also had to venture into estate management, with its 850,000 acres of land unfit for growing trees. This situation has arisen because landowners will rarely part with hill ground except in existing farming units, often including hill tops which may be fit only for grazing animals.

Recreation, education and conservation have all been important considerations during the commission's history. The forest park established in the Forest of Dean in 1938 now has seven camping sites, five adventure centres and five forest trails. Glenmore in the Cairngorm Mountains has the finest ski slopes in Scotland. Some forests have school plots, carefully chosen by the commission, where children can make fences, plant trees and study the wild life.

Woodlands are an excellent habitat for many rare wild animals and plants. Forests and nearby uplands contain some of Britain's rarest predators-wild cat, pole cat and pine marten - and among the birds there are golden eagles and occasionally ospreys. There are rare alpine plants on the higher slopes of some mountains, while the New Forest is the only home of the wild gladiolus (Gladiolus illyricus). And the commission recognizes its conservational responsibility, while at the same time controlling the more destructive creatures, such as deer which can jump any fence less than six feet high and wreak considerable damage to the trees.

\section{FOOD RESEARCH}

\section{New Home in Norwich}

WrтH the opening of the Food Research Institute in Norwich on April 26, the Low Temperature Research Station has now been fully rehoused. In 1956 the University of Cambridge, hard pressed for space, gave the station ten years to find new accommodation.
The Agricultural Research Council took over the station and decided to replace it with two new institutes, the Meat Research Institute, which was opened in Bristol last year, and the Food Research Institute, to be concerned with vegetables, fruit, eggs and poultry.

Last August the staff started to move into the new $\mathfrak{f 1}$ million building with its estimated $\mathfrak{f} 0.75$ million worth of equipment. There will be some facilities for food scientists from the Ministry of Agriculture, and the electron microscopy group and part of the virus research group from the nearby John Innes Institute will work in the new laboratories until their own are ready in 1970. There will also be a close relationship with the University of East Anglia, with the director of the institute, Dr S. R. Elsden, becoming a professor of biology with a seat on the senate. Members of the institute's staff who teach at the university will become honorary lecturers.

The objects of the Food Research Institute in general are those of the ARC-to help farmers to double the output of home produced food by the end of this century - and in particular this institute aims to ensure that they can produce first class vegetables, eggs, fish and poultry. The chemistry division, concerned principally with quality, keeping properties and changes

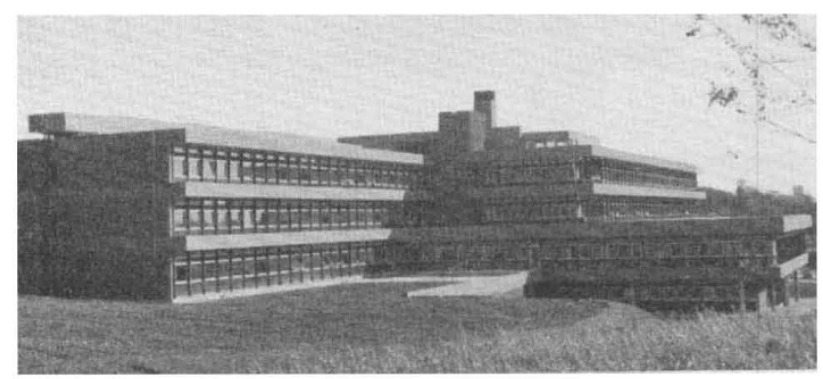

during storage, has a strong interest in taste. High resolution mass spectrometry and chromatography are being used to detect and identify the flavour volatiles of several foods, including potatoes, carrots, poultry and bananas. The idea is to find the normal pattern of taste substances, so that irregularities can then be identified easily. The human palate, however, is still considered to be the ultimate arbiter, and there are several taste panels made up of members of the institute staff.

The British Government first became aware of the need for food research during the First World War when spoilage was as much a problem as destruction by the enemy, and spoilage is still the principal concern of the microbiology division. Methods are being developed for the rapid detection and identification of spoilage microorganisms, and at the moment the division has a special interest in strictly anaerobic bacteria.

The plant biochemistry and physiology division has as its principal object the elucidation of the biochemical reactions that occur in fruit and vegetables after harvesting. If ways could be found of lengthening the time before ripening, storage life could be increased. There is already the prospect of controlling the ripening of bananas, for green bananas kept in an atmosphere of 5 per cent oxygen for six weeks do not ripen, but as soon as ethylene is added they ripen. The same thing can also be done with tomatoes and cucumbers. 